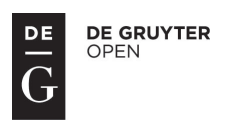

\title{
Criminal Liability of Legal Persons in Light of the SUBSIDIARITY OF CRIMINAL REPRESSION
}

\author{
Pavel Kotlán ${ }^{1}$
}

\begin{abstract}
This paper deals with the definition of (substantive) subsidiarity of criminal repression and the possibility of its application to the criminal liability of legal persons. After defining the liability of legal persons in the relevant legal regulations, the paper presents an interpretation of subsidiarity in Section 12(2) of the Criminal Code that is significantly different from the "official" opinion. Subsequently, the paper discusses certain criminal law situations in which the application of subsidiarity would lead to the conclusion that the legal person is not punishable ("non-criminality"). The first aim was thus to present the theoretical concept of subsidiarity of criminal repression, which would be methodologically correct, and therefore generally applicable. The second objective was directed at demonstrating that this construct can be applied to specific examples of the liability of legal persons, that is, that it can be applied to the activities of the bodies in charge of criminal proceedings.
\end{abstract}

\section{Keywords}

Subsidiarity, Criminality, Legal Person

\section{Introduction}

Current criminal law theory and its application in practice in the Czech Republic faces two issues which I believe are complementarily related: substantive subsidiarity of criminal repression and criminal liability of a legal person. The definition of the subsidiarity of criminal repression in Section 12(2) of the Criminal Code (Act No 40/2009 Sb., the Criminal Code, as amended, hereinafter the "CC") is often misinterpreted under the influence of the most significant professional opinion, which also has a negative impact on the decision-making practice of courts (including the Supreme court of the Czech Republic). If we apply the liability of a legal person for a criminal act, the fairly wide

${ }^{1}$ University of Economics in Ostrava, Mojmírovců 42, 70900 Ostrava, Czech Republic. E-mail: Pavel.Kotlan@seznam.cz. 
legislative definition leads to inappropriate punishment or, paradoxically, to ignoring the criminal liability of legal persons in general.

It should be noted that, although the prevailing interpretation of criminal law subsidiarity is subject to justified criticism, ${ }^{2}$ and so is the scope of liability of legal persons, I have never noticed the two issues to be linked, although it is undoubtedly something that suggests itself. The purpose of the present article is therefore to use a methodologically correct interpretation of the subsidiarity of criminal repression and its application to legal persons to present a meaningful theoretical insight, which would in turn become the basis for application by bodies in charge of criminal proceedings, or at least launch a much-needed discussion.

\section{A brief summary of the legal regulation of legal persons and their criminal liability}

A legal person is an artificial person, or, as defined by law, "an organized body whose legal personality is laid down or recognized by a statute" (Section 20(1) of Act No 89/2012 $\mathrm{Sb}$., the Civil Code). It is the Civil Code that provides the basis for the regulation of legal persons and unifies the basic rules governing their existence. ${ }^{3}$ In addition, the Civil Code also codifies the special regulation of associations, as well as rules governing companies (entrepreneur, corporate name, unfair competition, etc.). In the context of criminal acts committed by legal persons, it is necessary to mention the Business Corporations Act (Act No 90/2012 Sb., on business corporations, hereinafter the "Business Corporations Act"), which, to a greater or lesser extent, represents a special regulation governing the activities of business corporations (i.e. companies and cooperatives).

The criminal liability of legal persons is based on the provisions of the Criminal Code and Act No 411/2008 Sb., on the criminal liability of legal persons and proceedings against them, as amended (hereinafter the "Act on the Criminal Liability of Legal Persons"). In essence, this relationship is one of complementarity, where the rules governing criminal liability are primarily (but not in their entirety) laid down in the Act on the Criminal Liability of Legal Persons, while other rules are laid down in the Criminal Code (see the text of Section 1(2) of the Act on the Criminal Liability of Legal Persons: "Unless otherwise provided herein, the Criminal Code shall apply... ”). I will leave aside the disputability of the Act on the Criminal Liability of Legal Persons as a whole, and of the criminal liability of legal persons as such, ${ }^{4}$ and I will only focus on certain issues essential to the matter at hand. Criminal liability applies only to selected legal persons (Section 6 of the Act on the Criminal Liability of Legal Persons) and specific criminal acts (Section 7 of the Act on the Criminal Liability of Legal Persons), which is based on the concept of attribution - i.e. the criminalization of legal persons is based on the determination of whether a natural person acted on behalf of a legal person (Section 8 of the Act on the Criminal Liability of Legal Persons). With respect to the above, it is irrelevant whether a particular natural person that committed a criminal act has been determined; it is only

\footnotetext{
${ }^{2}$ E.g. Kratochvíl (2015).

${ }^{3}$ See the Explanatory Memorandum to the Civil Code, commentary on Sections 118 and 119.

${ }^{4}$ For more information, see, e.g. Šámal (2012), or Jelínek (2013).
} 
relevant whether or not the acts of the natural person can be attributed to the legal person (Section 8(3) of the Act on the Criminal Liability of Legal Persons). ${ }^{5}$ That said, the attributability is so extensive that criminal liability even passes to a legal successor of the legal person, regardless of whether such a successor is at fault. ${ }^{6}$

In practice, there have been (so far) great difficulties and imbalances in the way bodies in charge of criminal proceedings deal with the criminal liability of legal persons. Public records on convicted legal persons for a period from late 2013 to early 2016 show that 98 legal persons were convicted, 36 of these by the Municipal Court in Brno. ${ }^{7}$ This astounding territorial imbalance completely denies the increasingly accentuated requirement for the predictability of judicial decisions, i.e. that courts give analogous rulings in analogous cases. ${ }^{8}$ That said, one can hardly consider the decisions of the Municipal Court in Brno to constitute disproportionate criminal repression, but rather look at the bodies in charge of criminal proceedings in Brno as being more consistent and thorough in prosecuting legal persons. In other regions, these bodies seem reluctant (quite understandably so) to conduct often senseless and ineffective proceedings against a legal person. As a consequence, there is a general lack of interest in the prosecution of legal persons, which is perceived only as a complication in criminal proceedings against natural persons. It is also alarming that 42 legal persons were convicted of the failure to pay taxes, social security contributions and other mandatory payments in accordance with Section 241 of the Criminal Code, i.e. criminal acts where the punishment of a legal person is problematic, to say the least. ${ }^{9}$ Although 27 convictions for fraudulent crimes (in particular fraud in accordance with Section 209 of the Criminal Code and credit fraud in accordance with Section 211 of the Criminal Code) and 14 for evading taxes, fees and similar payments in accordance with Section 240 of the Criminal Code can be considered reasonable, in some cases criminal proceedings were (unnecessarily) brought against dysfunctional companies. A meaningful differentiation when deciding whether or not a legal person is to be punished could be achieved by a correct interpretation of a criminal act taking into account the subsidiarity of criminal repression (naturally, leaving aside the possibility of legislative amendments).

\footnotetext{
${ }^{5}$ The fundamental objective of the Act on the Criminal Liability of Legal Persons was to respond to an undesirable situation in which it was impossible to "punish a legal person involved in a criminal activity, even though the offender that has committed the criminal act demonstrably acted in the interest or in the name of such a legal person." The explanatory memorandum to the Act on the Criminal Liability of Legal Persons, commentary on the general part.

${ }^{6}$ The original (rejected) draft of the Act on the Criminal Liability of Legal Persons reasonably provided that criminal liability passes to the legal successor only if the successor knew or should have known, given the circumstances and the legal successor's situation, that the legal person had committed a criminal act. For more details, see Jelínek (2015).

${ }^{7}$ See details available at: https://eservice-po.rejtr.justice.cz/public/odsouzeni.

${ }^{8}$ For more details on the requirement, see, e.g. Judgment of the Constitutional Court of the Czech Republic of 5 September, 2012, file no. II ÚS 3/10. That said, the Act has been effective since 1 January, 2012, so one cannot refer to initial ambiguities in the application of law by different courts.

${ }^{9}$ The adequacy of such a punishment will be subject to interpretation in the last part.
} 


\section{III. (Substantive) subsidiarity of criminal repression}

The subsidiarity of criminal repression consists of an interconnected complex of legislative, substantive and procedural subsidiarity. Further considerations focus on substantive subsidiarity, which stands in the imaginary centre of the correction of criminal repression - that is, it follows up on the group of acts defined by legislative subsidiarity which are codified by the legislature as a criminal act, and it forms the basis to apply procedural subsidiarity, which takes into account the behaviour of the offender and his attitude to the criminal act. ${ }^{10}$

(Substantive) subsidiarity of criminal repression ${ }^{11}$ is codified in Section 12(2) of the Criminal Code: "The criminal liability of an offender and criminal-law consequences associated therewith may be applied only in socially harmful cases in which it is not sufficient to apply liability in accordance with another legal regulation."

Given that subsidiarity falls under criminal law, the interpretation of this provision must not only respect the meaning of the law (within the spirit of "cessante ratione legis cessat lex ipsa"12), but also a ban on the creation of law by analogy to the detriment of the offender. ${ }^{13}$ The framework of interpretation is therefore presented by linguistic interpretation; ${ }^{14}$ the actual interpretation is then based on arguments based on the noncontradiction of the values of the law, and on formally systematic arguments. ${ }^{15}$ Where multiple equivalent interpretative alternatives are found, it is impossible to use arguments based on subjectively-historical interpretation, but only the alternative which is consistent with the principle in dubio mitius (more leniently in the case of doubt, in favour of the offender). ${ }^{16}$

If we realize the above interpretive principles and rules of formal logic, the interpretation of codified subsidiarity is as follows. There are two cumulative conditions of criminality: sufficient social harmfulness and insufficient applicability of liability other than criminal liability (insufficiency of "non-punishment" 17 ). One must therefore reject the Opinion of the Criminal Division of the Supreme Court of the Czech Republic ${ }^{18}$ claiming that criminal liability does not apply in cases which "do not constitute the least serious commonly

\footnotetext{
${ }^{10}$ Previous regulation of substantive criminal law was based on the concept of dangerousness, which contained in itself elements of substantive and procedural subsidiarity (for more details, see Section 3(4) of Act No 140/1961 Sb., the Criminal Code, as amended).

${ }^{11}$ Where the paper further refers to subsidiarity (of criminal repression), it means its substantive form (unless explicitly stated otherwise).

12 "When the reason for a law ceases, the law itself ceases."

${ }^{13}$ For more details, see the judgment of the European Court of Human Rights of 25 May, 1993, Application No $14307 / 88$, Kokkinakis v. Greece.

${ }^{14}$ Linguistic interpretation represents "an initial approximation to the applied rule and the basis for the clarification of its meaning and purpose". Judgment of the Constitutional Court of the Czech Republic of 17 December, 1997, file no. Pl. ÚS 33/97.

${ }^{15}$ For more details, see Melzer (2011), and Wintr (2013).

${ }^{16}$ However, there is no reason for a reverse approach - i.e. in the context of objectively recent interpretation to give automatic preference to the argument in dubio mitius if it leads to a value conflict (Melzer, 2011).

${ }^{17}$ The notion of insufficiency of "non-punishment" is thus a necessary consequence of the concept of a criminal act as ultima ratio.

${ }^{18}$ Opinion of the Supreme Court of 30 January, 2013, file no. Tpjn 301/2012.
} 
occurring cases of such a criminal act, or, where, in addition to the punishment for such an act, it is sufficient to apply liability in accordance with another legal regulation.", because it is based on a formally logically erroneous assumption that only social harmfulness is a prerequisite of criminality (see the "or ... in addition"). However, social harmfulness and insufficiency of "non-punishment" are more or less equivalent elements of criminality, in other words, one can imagine that the absence of even one of them constitutes noncriminality. ${ }^{19}$

Subsidiarity in Section 12(2) of the Criminal Code is also a defining element of a criminal act, which is in line with the value concept of criminal law and the sanction policy of the State in general. Among the many arguments that show that subsidiarity is a (statutory) element of a criminal act, let me mention the most fundamental ones: The sanctions of the State against private persons, which the European Court of Human Rights subsumes under the concept of "criminal charge" 20 , can be in principle divided into administrative delicts and criminal acts. The statutory definition of an administrative infraction (i.e. an administrative delict of a natural person) reads as follows: "An administrative infraction is wilful conduct that violates or threatens the interest of society, and is specifically identified as such in this Act or any other act, unless the administrative infraction constitutes another administrative delict punishable under special legal regulations, or a criminal act" (Section 2(1) of the Administrative Infraction Act No 200/1990 Sb., as amended). The defining element of an administrative infraction is therefore social harmfulness (violation of or threat to the interests of society) as an element of subsidiarity. It would therefore be completely unsystematic and inconsistent in terms of values to have subsidiarity absent from the very concept of the more serious form of a public-law delict (criminal act). If we accept the opinion that subsidiarity is not the statutory element of a criminal act, it would bring with it absurd consequences it in certain situations. Consider an example: A body in charge of criminal proceedings would find that a criminal act has been committed, but it would simultaneously conclude that the act is not socially harmful (in terms of criminal law), and that liability for administrative infraction is sufficient for such an act to be punished. However, because the above body has found (formal) fulfilment of the statutory elements of a criminal act, it may not refer the administrative infraction for consideration (see the definition of an administrative infraction: “... unless ... it constitutes a criminal act”). The offender that has committed the delict therefore gets away without any sanction. ${ }^{21}$

\footnotetext{
${ }^{19}$ One could imagine a clearer wording of Section 12(2) of the Criminal Code, e.g. the following: An act constitutes a criminal act only if it has an increased degree of social harmfulness, and if non-criminal-law means are insufficient for its punishment.

${ }^{20}$ Article 6(1). European Convention on Human Rights (Communication of the Federal Minister of Foreign Affairs No 209/1992 Sb. on the European Convention on Human Rights, as amended by Protocols Nos 3, 5 and 8). It is therefore not about systematic classification, but about whether the nature and degree of severity of sanctions correspond to the criminal-law aspect. For more details, see the judgment of the European Court of Human Rights of 25 August, 1987, Application No 9912/82, Lutz v. Germany.

${ }^{21}$ The opinion in the decision of the Supreme Court stating that "one cannot a priori reject the possibility to consider actions formally showing signs of a criminal offence pursuant to Section 283(1) of the Criminal Code as an infraction in the healthcare sector" is therefore erroneous. See Resolution of the Supreme Court of the Czech Republic of 16 February, 2011, file no. 8 Tdo 112/2011.
} 
In the "official" opinion ${ }^{22}$, the Criminal Code is based on the so-called "formal" approach to a criminal act, where the "principle of subsidiarity of criminal repression and the ensuing principle of 'ultima ratio' is applied outside the definition of a criminal act". ${ }^{23}$ However, this view does not rely on any methodologically acceptable reason. ${ }^{24}$ After all, its proponents contradict themselves when they also argue that subsidiarity (social harmfulness) stands outside the definition of a criminal act, but at the same time admit, as the correct process solution for acts with low social harmfulness, procedures based on the assumption that an act is not a criminal act. ${ }^{25}$

If we were to express the relationship between social harmfulness and the insufficiency of a "non-punishment", I believe it would be appropriate to use the "doctrine of a type concept". The fulfilment of a type concept is - unlike in the case of a "conventional" classification concept - derived not only from the presence of a particular element, but also from the extent to which it is fulfilled. The question therefore is whether the number and extent of typical elements are sufficient for us to conclude that the (type) concept has been fulfilled. ${ }^{26}$ The intensive presence of one of the elements can even compensate for the absence of another. ${ }^{27}$ The type concept would therefore correspond to the definition of codified subsidiarity - i.e. significantly reduced presence of social harmfulness and lower presence of the insufficiency of "non-punishment", or a complete absence of social harmfulness (regardless of the sufficiency of non-criminal punishment) mean that an act is not a criminal act. Naturally, the reverse is also true, which is absolutely essential for the criminal liability of legal persons: the possibility to strongly apply the sufficiency of a "non-punishment" in combination with a reduced degree of social harmfulness, or even the very sufficiency of the application of liability under other legal regulations (for a socially harmful act) may be the reason to conclude non-criminality.

\section{Application to criminal liability of legal persons}

Within the meaning of Section 1(2) of the Act on the Criminal Liability of Legal Persons, the criminality of legal persons is also considered in accordance with Section 12(2) of the Criminal Code. However, as already mentioned, the criminal liability of legal persons is based on the concept of attribution. Therefore, if a criminal act is (in terms of criminal law) socially harmful in relation to the criminal liability of a natural person (and, naturally, it is not sufficient to apply non-criminal liability against such a person), it is attributed to the legal person. ${ }^{28}$ Therefore, it is impossible to examine social harmfulness in relation

\footnotetext{
${ }^{22}$ These proponents include experts close to Pavel Šámal, the current President of the Supreme Court, who is the de facto creator of the Criminal Code, and whose interpretation is also dominant in the decisions of the Supreme Court through the most important commentary on criminal-law regulations (published by C. H. Beck).

${ }^{23}$ See the Explanatory Memorandum to the Criminal Code, commentary on Sections 12 and 13.

${ }^{24}$ The actual Explanatory Memorandum - as an argument of subjective historical interpretation - is not admissible in criminal law. See Melzer (2011).

${ }^{25}$ See Opinion of the Supreme Court of the Czech Republic, file no. 301/2012, points ad V and VI.

26 “... Merkmale in solcher Zahl und Stärke vorhanden sind, dass der Sachverhalt 'im Ganzen' dem Typus entspricht”. Bydlinski (1991).

${ }^{27}$ Melzer (2011).

${ }^{28}$ This is in line with the private law concept of a legal person, which is a fiction in accordance with Section 151 of the Civil Code, i.e. a legal person does not have its own will, its will is replaced by the will of natural persons
} 
to the criminality of a legal person, because it is already given (objectively) by identifying the harmfulness of an act of a natural person. On the other hand, it is necessary to consider the element of the inadequacy of "non-punishment". ${ }^{29}$ Therefore, the finding that the defining elements of a criminal act of a natural person (including subsidiarity) have been fulfilled does not relieve the bodies in charge of criminal proceedings of the duty to deal with subsidiarity when assessing the criminality of a legal person, namely whether or not liability under other legal regulations constitutes adequate legal remedy. In turn, the argument a minori ad maius, i.e. an argument of value non-contradiction ${ }^{30}$, allows us to conclude that the application of criminal liability of a natural person may also be a reason not to apply criminal liability of a legal person on behalf of which the natural person acted. The reason for this is that if the application of liability under other legal regulations may in some cases be the reason for the non-fulfilment of criminality, the application of criminal liability may all the more so be the reason.

Therefore, if a natural person has been found culpable for an act which is to be attributed to a legal person, our attention should focus on the (in)sufficiency of the "non-punishment". However, this does not mean that in the context of subsidiarity we should not continue to consider social harmfulness, because in dealing with the subsidiarity of criminal repression as a whole, i.e. including legislative subsidiarity, we can identify the elements of criminal acts which in themselves contain lower social harmfulness. I believe that it is these criminal acts where "even" a significant degree of sufficiency of the application of non-criminal liability could indicate non-criminality of a legal person. ${ }^{31}$ I consider such inherently less socially harmful criminal acts to include, e.g. criminal acts without qualified elements, negligent property criminal acts or property criminal acts without a lower limit of damage (or, conversely, the basic elements with minimum damage which is higher than nonnegligible), criminal acts penalizing the mere failure to fulfil a duty (of "non-fraudulent" nature), and those where the removal of the effect automatically terminates criminality (i.e. a special effective repentance). In other words, one can reasonably imagine that if these criminal acts were not codified, the protection of society would not be significantly diminished.

While social harmfulness is an expression of an intervention in protected social interests, i.e. a relatively constant category, whether there is currently a sufficient non-criminal remedy in relation to the act is the reflection of the current state of the rule of law, i.e. a variable category. If, in the context of the rule of law, we generally deliberate situations which could lead to the non-criminality of a legal person, while maintaining the criminality of the natural person, we can identify three basic alternatives:

(acting on its behalf) attributed to the legal person. Štenglová, Dědič, Tomsa et al. (2014).

${ }^{29}$ This fact points to a further negative consequence of the official opinion: If non-criminality is, in principle, inferred from the absence of social harmfulness, the subsidiarity of criminal repression cannot be applied to criminal liability of legal persons at all.

${ }^{30}$ Melzer (2011).

${ }^{31}$ Of course, it is also necessary to have this in mind when the social harmfulness of a specific act of a natural person which is to be attributed to the legal person is reduced. 
(1) There is a statutory (non-criminal-law) procedure under which public authorities must act (i.e. ex officio). Its outcome is so adverse for the wrongdoer that it is equivalent to the expected criminal sanction (ideally, it is equal to the severest possible punishment). ${ }^{32}$

(2) The application of criminal-law means against a legal person constitutes, in relation to other legal instruments at the disposal of the public authority, a manifestly disproportionate measure of the State, and is ultimately significantly inefficient or unjust (with regard to the sanctioning of another entity that has committed a similarly socially harmful act). In this respect, subsidiarity primarily acts as a kind of stabilizing means balancing the imperfection of positive law.

(3) The social harm of an act is reduced due to a lower degree of social harm of an element of the criminal act or the merits of such a criminal act, which, in combination with a strong application of liability under other legal regulations, leads to the conclusion that criminal punishment of a legal person is not subsidiary.

Let us examine these alternatives in two situations abundant in practice: (1) situations where the suspected company is a dysfunctional company, i.e. a company not actually pursuing any activity or a company that pursues activities which are (mostly) illegal; and (2) the area of tax crimes.

If criminal proceedings are brought against a company that pursues no actual business activities or operates illegally, it is evident that the effect of such proceedings is minimal or non-existent, and basically it only leads to inefficient management of public funds. ${ }^{33}$ The legal solution to this situation is a combination of primary legal means to prevent the existence of such companies, and subsidiarity of criminal repression. This then leads to the identification of whether or not the application of liability in accordance with other legal regulations is sufficient. By primary means I am referring to the so-called "forced liquidation", which is regulated primarily by Section 172 of the Civil Code and Section 93 of the Business Corporations Act. The most common situation is a company that does not pursue any real activity - a so-called "dead company" or a "passive company". ${ }^{34}$ Such a company is covered by Section 93(b) of the Business Corporations Act, which provides that on the application of "the person that has a legal interest therein or on the application of the State prosecutor, if he finds substantial public interest therein, a court shall dissolve a business corporation if it is unable to pursue its activities and fulfil its purpose for more than one year". This provision basically takes over part of the former provision of Section 68(6)(a) of Act No 513/1991 Sb., the Commercial Code, as amended (the Commercial Code). One can (therefore) agree with the opinion that a company is dysfunctional in the sense that it is "impossible to establish legal relationships with it (dysfunctional governing bodies), or the company is unable to make fundamental decisions necessary

\footnotetext{
${ }^{32}$ In addition to the dysfunctional companies analysed below, this also concerns legal persons in liquidation or in insolvency proceedings after the declaration of bankruptcy.

33 The offenders can relatively easily continue with their activity using any other (dysfunctional) company.

${ }^{34}$ See Stehlík (2016).
} 
for its operation (e.g. approve annual accounts ... )". ${ }^{35}$ Since a civil court will proceed according to the Special Court Proceedings Act, ${ }^{36}$ the proceedings are governed by the principle of investigation, ${ }^{37}$ i.e. the responsibility for clarification of the elements lies with the court. ${ }^{38}$ This indicates that if a body in charge of criminal proceedings finds a company which is inactive in relation to other entities and impossible to contact (nonfunctional or non-existent website, e-mail or other contact information, no use of data box, no business premises, cannot be contacted at the registered office or elsewhere, or even by mail, no tax return filings, etc.), or fails to meet the basic legal requirements relating to the internal functioning (especially the failure of a capital company to hold general meeting ${ }^{39}$, and failure to approve the annual accounts ${ }^{40}$ ), the State prosecutor should apply to the competent civil court to commence proceedings to dissolve the company and terminate criminal proceedings against the legal person. ${ }^{41}$ This is because by applying consistent interpretation, we will necessarily come to the only possible conclusion: if the sanction likely to be imposed in civil proceedings is equal to the maximum possible sanction (for a legal person) in criminal proceedings (i.e. the dissolution of the legal person within the meaning of Section 16 of the Act on the Criminal Liability of Legal Persons), criminal proceedings are non-subsidiary in the matter and do not reflect the secondary role of criminal law.

The caveat that after presenting evidence in (uncontentious) civil proceedings, the court does not find any facts justifying the forced liquidation of the company, thereby allowing the legal person to escape criminal liability, can be addressed as follows: If a (civil) court is adequately informed through the State prosecutor's application of the (criminal law) status,

\footnotetext{
35 Pokorná (2009).

${ }^{36}$ See Section 3(2)(a) and (b) of Act No 292/2012 Sb., on special judicial proceedings, as amended by Act No 87/2015 Sb. (hereinafter the Special Judicial Proceedings Act).

37 Štenglová, Dědič, Tomsa et al. (2014).

38 Winterová, Macková (2015).

39 The obligation to convene the General Meeting as the supreme body of capital companies is provided in Section 181(1) of the Business Corporations Act (limited liability company) and Section 402(1) of the Business Corporations Act (joint-stock company). Given that the failure to convene the General Meeting was one of the explicitly expressed reasons for forced liquidation in Section 68(6)(a) of the Commercial Code, and the regulation of Section 93(b) is actually its more general modification (see, e.g. the Explanatory Memorandum to the Business Corporations Act, commentary on Section 93), the failure to convene regular (annual) General Meeting is clearly a reason for the dissolution of a company.

${ }^{40}$ As accounting entities, companies have an obligation to prepare annual accounts for the accounting period (Section 14 of Act No 563/1991 Sb., on accounting, as amended), and then publish it in the collection of documents (Section 21(2) and (4) of the Accounting Act). Annual accounts are approved by the General Meeting of a capital company (Section 181(2) of the Business Corporations Act and Section 403(1) of the Business Corporations Act). The fact that annual accounts are not filed in the collection of documents therefore constitutes certain indication that they were not even compiled/approved, and that the company therefore fails to fulfil one of the statutory prerequisites of its existence.

${ }^{41}$ Depending on the phase of preparatory proceedings, this would mean either discontinuing the case in accordance with Section 159a(1) of the Code of Criminal Procedure or discontinuing criminal prosecution in accordance with Section 172(1)(a) of the Code of Criminal Procedure. If we accept the view that subsidiarity of criminal repression is not an element of a criminal act, we would face a problem of how to terminate criminal proceedings, because it would be impossible to discontinue the case (criminal prosecution) by referring to the fact that it does not involve a criminal act.
} 
the court is aware (see principle iura novit curia) that the non-dissolution of a company is usually the reason for the continuation of criminal proceedings against the legal person (i.e. the element of sufficiency of the application of non-criminal law means is no longer significant), and informs (ex officio) the competent body in charge of criminal proceedings of its decision. ${ }^{42}$

After all, if we were to look at the issue of dysfunctional companies from another perspective, we would probably also conclude non-criminality due to the very nature of attribution. This is because a dysfunctional company is in most cases the result of a situation where the persons associated with its activities (a governing body, partner, corporate agent, etc.) committed a criminal act (fraud in accordance with Section 209 of the Criminal Code, damaging of creditors in accordance with Section 222 of the Criminal Code, tax evasion in accordance with Section 240 of the Criminal Code, etc.) and then "got rid" of the company. Therefore, the aim of the offenders was not to perform the criminal act to benefit the company (which, soon after the act, is represented by completely different personnel), but only to enrich themselves as natural persons. Usually, the criminal act burdens the company with another obligation (whether of a private law nature or, e.g. the obligation to pay the assessed tax plus statutory late payment interest (see Section 251 of Act No 280/2009 Sb., the Tax Code, as amended, hereinafter the Tax Code)). Then, however, it is totally against the spirit of attributability (in terms of subsidiarity) to also punish the legal person for a criminal act of a natural person. ${ }^{43}$

In the case of a company conducting business illegally (i.e. in fact also a dysfunctional company in the broader sense), it is necessary to similarly apply forced liquidation through a civil court. In accordance with Section 172(1)(a) of the Civil Code, a court shall dissolve (even by its own motion) a legal person which "carries out illegal activities to such an extent that it seriously disrupts public order". The dissolution of a legal person as a punishment in the criminal proceedings against a legal person may be imposed by a court if "its activity consisted wholly or dominantly in the commission of criminal act(s)" (Section 16(1) of the Act on the Criminal Liability of Legal Persons). Dominant commission of criminal acts can be certainly subsumed under illegal activities disrupting public order. This indicates that all acts to which dissolution of a legal person could be applied are subject to the authority of a "non-criminal" court. Even if in the case of this company, it is not appropriate to conduct criminal proceedings.

For the above reasons, criminal acts attributable to a legal person also exclude conduct in a situation which corresponds to other alternatives of forced liquidation - in practice, this will primarily involve a legal person which has not had a governing body able to constitute a quorum for more than two years (Section 172(1)(c) of the Civil Code).

\footnotetext{
${ }^{42}$ In addition, if the applicant is the State prosecutor, the State prosecutor becomes a party to the proceedings (see Section 6 of the Special Judicial Proceedings Act).

${ }^{43}$ There is a large degree of consensus that it is not appropriate to pursue a legal person if the act has been committed to its detriment. See, e.g. Šámal (2015), or the Resolution of the Supreme Court of the Czech Republic of 24 November, 2015, file no. 8 Tdo 627/2015.
} 
At the end of the paper, I will focus on the area of tax crime, where the criminal liability of legal persons is significantly present in practice, as mentioned above.

The reduced degree of social non-harmfulness is immanent to a criminal act consisting of the failure to pay insurance premiums and taxes for employees pursuant to Section 241 of the Criminal Code, because it is a "non-fraudulent" criminal act with special effective repentance (Section 242 of the Criminal Code) - meaning impunity when the debt is paid, ${ }^{44}$ and in this case the State has strong legal means for its enforcement (including administrative private enforcement). In this context, it is necessary to reflect the conclusion of the Supreme Administrative Court, which, essentially correctly, considers statutory late payment interest in accordance with Section 251 of the Tax Code to be a form of punishment for criminal charges (see the said Article 6(1) of the Convention), and, therefore, the simultaneous imposition of both the statutory late payment interest, and punishment in criminal proceedings to be a breach of the principle ne bis in idem. ${ }^{45}$ Although the statutory late payment interest for the failure to timely pay insurance premiums and taxes for employees has the nature of late payment interest, ${ }^{46}$ it is still a sanction of the State against a private entity, i.e. its nature is close to punishment. ${ }^{47}$ Therefore, if it is impossible to conclude criminal liability of a legal person for tax evasion where the taxpayer/legal person is sanctioned in the form of statutory late payment interest in accordance with Section 251 of the Tax Code, ${ }^{48}$ it does not seem reasonable to insist on the criminalization of non-payment of taxes/premiums, whose elements are less serious and which is punishable with a different kind of statutory late payment interest. ${ }^{49}$ It should be noted that the punishments which may be imposed on a legal person for this criminal act include in particular pecuniary punishment (Section 15 of the Act on the Criminal Liability of Legal Persons). As a result, criminal proceedings against the legal person would only lead to an increase in its debt (consisting of unpaid levies and assessed statutory late payment interest). I consider such exercise of public authority, which punishes breach of obligation by repeatedly increasing the financial liabilities of a legal person towards the State, to be neither subsidiary, nor effective.

Even the criminal act of evading taxes, fees and other mandatory payments in accordance with Section 240 of the Criminal Code can, despite its serious elements, generate situations where the punishment of a legal person is disproportionate/non-subsidiary. An example of this is a criminal act of a sole shareholder and managing director of a limited liability

\footnotetext{
${ }^{44}$ It is obvious that this is only a means to recover the debt owed to the State. Basically, this does not involve any effective repentance, but a pragmatic way to avoid criminal conviction.

45 Opinion of the Supreme Court of the Czech Republic of 24 November, 2015, file no. 4 Afs 210/2014.

${ }^{46}$ See Section 252 of the Tax Code, Section 20 of Act No 589/1992 Sb., on social security, as amended, and Section 18 of Act No 592/1992 Sb., on health insurance premiums, as amended.

${ }^{47}$ After all, it is possible to expect developments in this respect, because statutory late payment interest assessed in connection with additionally assessed tax was not interpreted as a punishment in earlier case law (see, e.g. Resolution of the Supreme Administrative Court of the Czech Republic of 28 April, 2011, file no. 1 Afs 1/2011). ${ }^{48}$ When tax is assessed additionally, which is the case equivalent to the criminal situation of tax evasion under Section 240 of the Criminal Code, the obligation to pay the statutory late payment interest is laid down by law (see Section 251(1) of the Tax Code).

${ }^{49}$ Also taking into account the fact that the Czech word for statutory late payment interest - "penále" - comes from the Latin word "poena" - punishment.
} 
company, who evaded tax and subsequently sold his share in the business for a considerable amount to another person (which is obviously reflected in the change in the governing body). Only after this transfer does the criminal act come to light, with the circumstances clearly indicating that the new shareholder did not know about the criminal act. The company with the new owner should therefore bear the burden of the higher tax assessment, as well as the punishment for the company. I believe that in similar cases the application of criminal liability of a natural person is a sufficient remedy and, given the text of codified subsidiarity in connection with the use of the argument a minori ad maius, it means non-criminality of the legal person. If the conduct of the new owner of the company upon the transfer of the company share is in good faith and meets the criteria of reasonable caution in legal relations (see in particular Section 4 and section 5 of the Civil Code), such a criminal punishment would be disproportionate and unjust. After all, the overall concept of law indicates that liability should be applied for conduct that is (objectively) within the realm of the affected person.

The application of this approach is naturally not bound within the limits of tax criminal law. The conclusion that a legal person becomes released from criminal liability if the new owner, acting in good faith, acquires the entire share of the company is also applicable to other criminal acts of legal persons. ${ }^{50}$ And, naturally, this part of subsidiarity should also apply by analogy to assessing the criminal liability of a legal successor of the legal person (see Section 10 of the Act on the Criminal Liability of Legal Persons).

\section{Conclusion}

The analysis resulted in the finding that the subsidiarity of criminal repression, codified in Section 12(2) of the Criminal Code, constitutes the defining element of a criminal act. It is composed of two equal elements: social harmfulness and the inadequacy of the application of liability under other legal regulations (insufficiency of "non-punishment"). The degree of fulfilment of these elements is decisive for the conclusion whether or not a particular act constitutes a criminal act.

Correct interpretation implies that even a significantly increased or maximum degree of sufficiency of non-criminal liability for socially harmful conduct is the reason for noncriminality. Therefore, the authors of Section 12(2) of the Criminal Code - probably unwittingly - gave independence to the insufficiency of "non-punishment", as a necessary consequence to the concept of a criminal act as ultima ratio. However, I consider such a legislative situation to be appropriate and to reflect the function of criminal law in the society. By identifying whether the application of liability under other legal regulations (including the liability of a natural person under the Criminal Code whose act should be

\footnotetext{
${ }^{50}$ Currently, an amendment to the Act on the Criminal Liability of Legal Persons is undergoing a legislative process which envisages that a legal person would be released from liability if it is proved that it "made every effort that could be reasonably required from it to prevent the commission ... (of the wrongful act)." This would resonate with the aforementioned considerations of subsidiarity. See government draft of the act available at: http://www.psp.cz. Unlike the politicians in their media statements, I do not believe that the mere existence of a code of et/hics is sufficient reason for release from liability.
} 
attributed to the legal person) is sufficient, we can respond to manifestly unfounded differences in criminal repression, which reflect the imperfections of the legal system. This is evidenced by the application to criminal liability of legal persons in the above cases. I believe that the interpretation of subsidiarity of criminal repression can help bodies in charge of criminal proceeding $\mathrm{s}^{51}$ to avoid in certain cases the absurd and fundamentally inappropriate criminal prosecution of a legal person.

\section{References}

Act No 140/1961 Sb., the Criminal Code, as amended.

Act No 141/1961 Sb., Code of Criminal Procedure, as amended.

Act No 280/2009 Sb., the Tax Code, as amended.

Act No 292/2012 Sb., on special judicial proceedings, as amended by Act No 87/2015 Sb.

Act No 589/1992 Sb., on social security, as amended.

Act No 592/1992 Sb., on health insurance premiums, as amended.

Act No 90/2012 Sb., Business Corporations Act.

Bydlinski, F. (1991). Juristische Methodenlehre und Rechtsbegriff. 2nd edition. Vienna, New York: Springer-Verlag.

Criminal Record of Legal Entities. Available at https://eservice-po.rejtr.justice.cz/public/odsouzeni.

European Convention on Human Rights (Communication of the Federal Minister of Foreign Affairs No 209/1992 Sb. on the European Convention on Human Rights, as amended by Protocols Nos 3, 5 and 8).

Explanatory Memorandum to the Business Corporations Act.

Explanatory Memorandum to the Criminal Code, commentary on Sections 12 and 13.

Jelínek, J. (2013). Trestní odpovědnost právnických osob v České republice - bilance a perspektivy. Prague: Leges.

Jelínek, J. (2015). K přechodu trestní odpovědnosti právní osoby na právního nástupce. Bulletin advokacie, (5), 21-25.

Judgment of the Constitutional Court of the Czech Republic of 17 December, 1997, file no. Pl. ÚS 33/97.

Judgment of the Constitutional Court of the Czech Republic of 5 September, 2012, file no. II ÚS 3/10.

Judgment of the European Court of Human Rights of 25 August, 1987, Application No 9912/82, Lutz v. Germany.

Judgment of the European Court of Human Rights of 25 May, 1993, Application No 14307/88, Kokkinakis v. Greece.

Kratochvíl, V. (2015). Případ, trestný čin, společenská škodlivost a vina v trestním právu (o zásadě subsidiarity trochu jinak). Právní rozhledy, (7), 537-559.

Melzer, F. (2011). Metodologie nalézání práva: úvod do právní argumentace. 2nd ed. Prague: C. H. Beck.

${ }^{51}$ In essence, there is no reason why any of these bodies should not have the right/duty to interpret the elements of a criminal act - including subsidiarity. 
Opinion of the Supreme Court of 30 January, 2013, file no. Tpjn 301/2012.

Opinion of the Supreme Court of the Czech Republic of 24 November, 2015, file no. 4 Afs 210/2014.

Opinion of the Supreme Court of the Czech Republic, file no. 301/2012.

Pokorná, J. (2009). Obchodní zákoník: komentár. Prague: Wolters Kluwer ČR.

Resolution of the Supreme Administrative Court of the Czech Republic of 28 April, 2011, file no. 1 Afs 1/2011.

Resolution of the Supreme Court of the Czech Republic of 16 February, 2011, file no. 8 Tdo 112/2011.

Resolution of the Supreme Court of the Czech Republic of 24 November, 2015, file no. 8 Tdo 627/2015.

Šámal, P. et al. (2012). Trestní odpovědnost právnických osob: komentár̆. Prague: C. H. Beck.

Stehlík, O. (2016). Nucené zrušení společnosti s.r.o. po rekodifikaci. Wolters Kluwer ČR. Štenglová, I., Dědič, J., Tomsa, M. et al. (2014). Základy obchodního práva. Prague: Leges. Tax Code.

Winterová, A., Macková, A. (2015). Civilní právo procesní. Část druhá. Prague: Leges. Wintr, J. (2013). Metody a zásady interpretace práva. Prague: Auditorium. 